MEDIA CAPTURE 



\section{Media Capture}

HOW MONEY, DIGITAL PLATFORMS, AND

GOVERNMENTS CONTROL THE NEWS

\section{Edited by Anya Schiffrin}


Columbia University Press

Publishers Since 1893

New York Chichester, West Sussex

cup.columbia.edu

Copyright $\odot 2021$ Columbia University Press

All rights reserved

Library of Congress Cataloging-in-Publication Data

Names: Schiffrin, Anya, 1962- author.

Title: Media capture : how money, digital platforms, and governments control the news / edited by Anya Schiffrin.

Description: New York : Columbia University Press, [2021] | Includes

bibliographical references and index.

Identifiers: LCCN 2020048105 (print) | LCCN 2020048106 (ebook) | ISBN 9780231188821

(hardback) | ISBN 9780231188838 (trade paperback) | ISBN 9780231548021 (ebook)

Subjects: LCSH: Freedom of the press. | Mass media and business. |

Government and the press. | Press and politics. | Social media-Influence. |

Internet industry-Influence. | Journalism-Objectivity.

Classification: LCC PN4735 .M435 2021 (print) | LCC PN4735 (ebook) | DDC 323.44/5-dc23

LC record available at https://lccn.loc.gov/2020048105

LC ebook record available at https://lccn.loc.gov/2020048106

Columbia University Press books are printed on permanent and durable acid-free paper.

Printed in the United States of America

Cover design: Julia Kushnirsky

Cover image: (๑) istockphoto 